\section{Oral Findings and Dental Treatment in a Childwith Williams-Beuren Syndrome}

Carolina Paes Torres, Gleice Valadares, Mariana Izabella Martins, Maria Cristina Borsatto, Kranya Victoria Díaz-Serrano, Alexandra Mussolino de Queiroz
Department of Pediatric Clinics, Dental School of Ribeirão Preto, USP - Universidade de São Paulo, Ribeirão Preto, SP, Brazil

Correspondence: Dra. Carolina Paes Torres, Avenida do Café, S/N 14.040-904 Ribeirão Preto, SP, Brasil. Tel: +55-16-3602-4143. e mail: caroltorres@forp.usp.br

\begin{abstract}
Williams-Beuren syndrome (WBS), also known as Williams syndrome, is a rare congenital disorder involving cardiovascular problems, mental retardation, distinctive facial features and tooth anomalies. It is caused by the submicroscopic deletion of 1.5 to $1.8 \mathrm{Mb}$ on chromosome 7q11.23. This paper reports the dental care to a 7-year-old child with WBS syndrome. The interview also revealed visual impairment, sensorineural hearing loss, hyperacusis, photophobia and hoarse voice. The intraoral clinical examination showed anterior open bite, tongue thrusting, excessive interdental spacing, enamel hypomineralization of the incisors, hypoplasia and caries lesions. The dental treatment included: modulating sessions to control aversion to noises, the photophobia, and the dental fear and anxiety because of his reduced visual acuity; oral hygiene instructions, dietary and daily use of a $0.05 \%$ sodium fluoride mouthwash; the permanent mandibular left first molar was treated endodontically, and maxillary and mandibular first molars were restored with amalgam. Due to the patient's heart defect, a prophylactic antibiotic regimen was prescribed prior to the dental procedures. This patient has been followed up for 4 years and this case report underscores the importance of early dental evaluation and counseling for parents of WBS patients.
\end{abstract}

Key Words: Williams syndrome, Williams-Beuren syndrome, oral care, tooth anomalies.

\section{Introduction}

Williams-Beuren syndrome (WBS MIM ID \#194050), also known as Williams syndrome, was first described by Dr. J. C. P. Williams and Dr. A. J. Beuren. This multisystemic, congenital and panethnic disorder is characterized by a number of hallmark physical features and developmental abnormalities (1).

WBS is caused by a microdeletion of approximately 1.5 to $1.8 \mathrm{Mb}$ on chromosome $7 q 11.23$ (1). Because an autosomal dominant inheritance pattern has been established, affected individuals have a 50\% chance of transmitting the disorder to their offspring. For healthy parents who have a child with WBS, the recurrence risk is usually low (2).

Recent epidemiological surveys (3) suggest that the prevalence could be as high as 1 in 7.500, but the incidence may be even higher because of underdiagnosis (2). The disorder has no sex, race or ethnic predilection (4).

Williams syndrome is characterized by dysmorphic facies $(100 \%)$, cardiovascular disease $(80 \%)$, most commonly supravalvar aortic stenosis, mental retardation (75\%), a characteristic cognitive profile (90\%) and idiopathic hypercalcemia $(15 \%)(1,5,6)$.

Facial dysmorphology is considered to be a major diagnostic feature in patients with WBS (5). It is composed of soft tissue and skeletal components such as wide smile and open mouth, thick lips, depressed nasal bridge with broad nasal tip, broad forehead, flattened midface, curly hair, prominent ears, anteverted nostrils, long philtrum, full cheeks, deficient chin, a higher than normal prevalence of Class II and III occlusions, open and deep bites, and anterior crossbite $(4,6-8)$.

Oral findings include enamel hypoplasia, abnormal tooth morphology, excessive interdental space, microdontia and tapered or screwdriver shaped incisors $(4,8)$.

The literature has numerous case reports on WBS, but there is very little information on the oral care for persons with this syndrome. This paper addresses the common oral findings in pediatric patients with WBS, discusses the strategies to deal with them during dental treatment, and reports the dental care to a 7-year-old child diagnosed with this syndrome.

\section{Case Report}

Ethics Committee approval (Process \#0095.0.138.00009) and parental written informed consent were obtained for case report and disclosure of child's uncovered photographs.

A 7-year-old Caucasian male child was brought to the Clinic of the Center of Formation of Human Resources Specialized in Dental Care for Special Patients at the Ribeirão Preto Dental School, University of São Paulo, Brazil, for general dental treatment. The patient was referred to our service by the Clinics Hospital of the Ribeirão Preto Medical School, University of São Paulo, where the diagnosis of WBS had been established. 
The child was born when his mother was 21 years old. There was no family history of the syndrome. The mother revealed that she did not have any complications during pregnancy. The child received a blood transfusion due to anemia at the age of 2 years old and later was diagnosed with supravalvular aortic stenosis, needing catheterization at the age of 7 years. Surgery for correction of inguinal hernia has also been performed. The child is under use of an angiotensin converting enzyme (ACE) inhibitor (Captopril, $2.0 \mathrm{mg} / \mathrm{kg} ; 8 / 8$ hours/day), for the treatment of congestive heart failure.

He is a very communicative and sociable child, loves listening to music and has a good auditory memory. He has delayed speech acquisition and mental retardation. He has also great difficulty in school activities and in handling tasks that involve motor coordination, such as drawing, cutting paper, tying the shoes and riding a bicycle.

The physical examination revealed albinism, normal stature for his age, sloping shoulders, normal walking, pectus excavatum, umbilical hernia and hypoplastic nails (Fig. 1). Distinctive craniofacial features included curly blond hair, medial eyebrow flare, flat midface, periorbital fullness (puffy eyes), epicanthal folds, long philtrum, depressed nasal bridge with broad nasal tip, anteverted nostrils, stellate pattern of iris, green eyes and strabismus
(Fig. 2). The patient also presented visual impairment, sensorineural hearing loss, hyperacusis, phonophobia and hoarse voice.

The intraoral clinical examination revealed anterior open bite, tongue thrusting, excessive interdental spacing, enamel hypomineralization of the incisors, hypoplasia and caries lesions in the maxillary and mandibular first molars. The radiographic exam showed sequence and chronology of eruption compatible with his age and agenesis of the mandibular right second premolar (Fig. 3).

The dental treatment was performed in the dental office under local anesthesia, after few modulating sessions employing the basic behavior guidance recommended by the AAPD Guideline on behavior guidance for pediatric dental patients (2011-2012) (9), because the child was initially uncooperative and resistant to the treatment, expressing dental fear and anxiety. As the child had significantly reduced visual acuity, he was allowed to touch the instruments to be used (e.g.: high-speed handpiece, explorer, three-way syringe and dental mirror) to make him feel more familiar with the dental setting, which reduced his fear and anxiety and helped establishing a strong bond with the dental staff. Because of his strong attraction to music, a pair of headphones was offered during treatment sessions so he could listen to his favorite songs and become
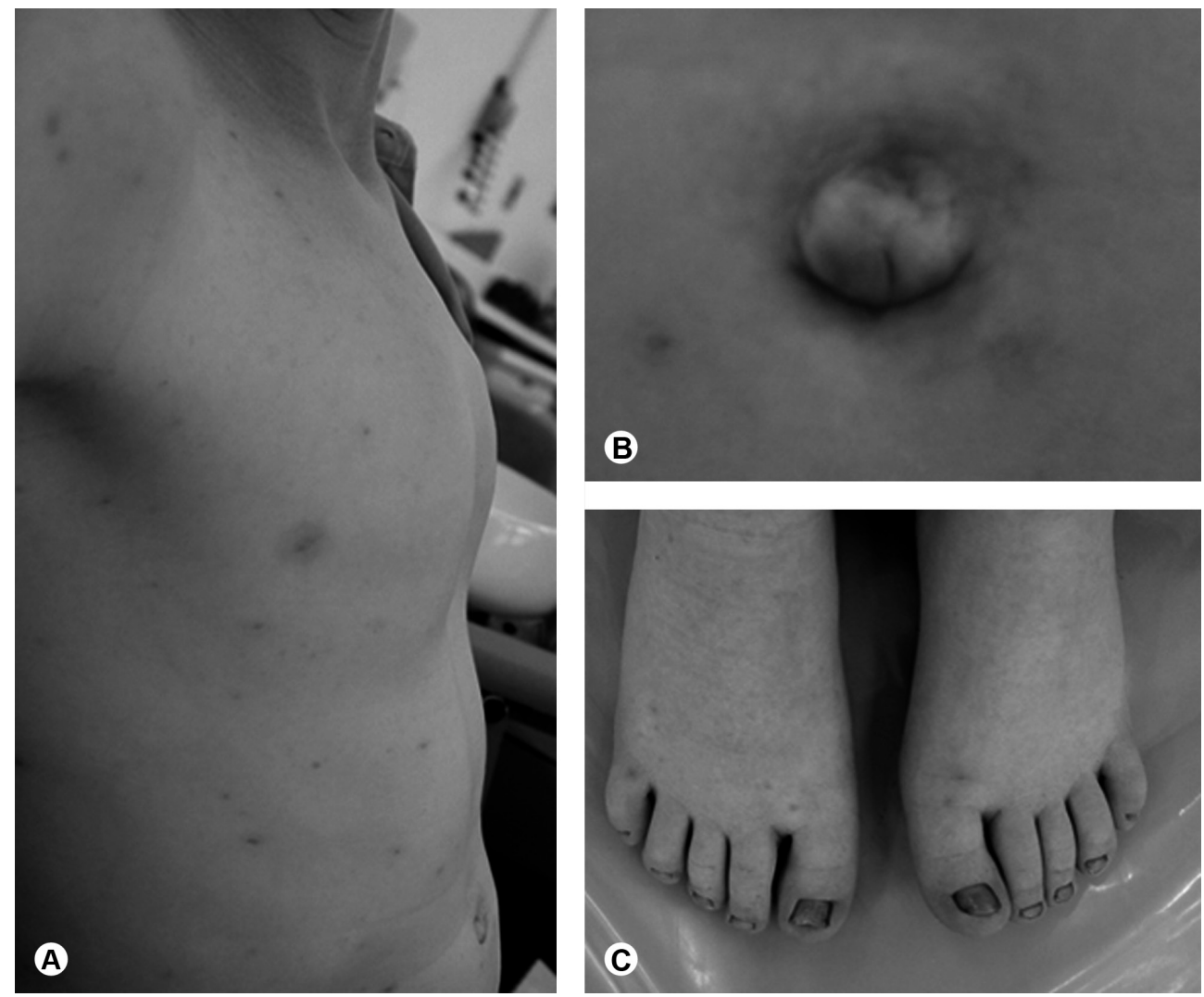

Figure 1. Physical characteristics: A: pectus excavatum; B: umbilical hernia; C: hypoplastic nails. 
more relaxed. The staff also perceived that the dental chair operating light was very disturbing to the patient because he had photophobia, and so a pair of sunglasses was also
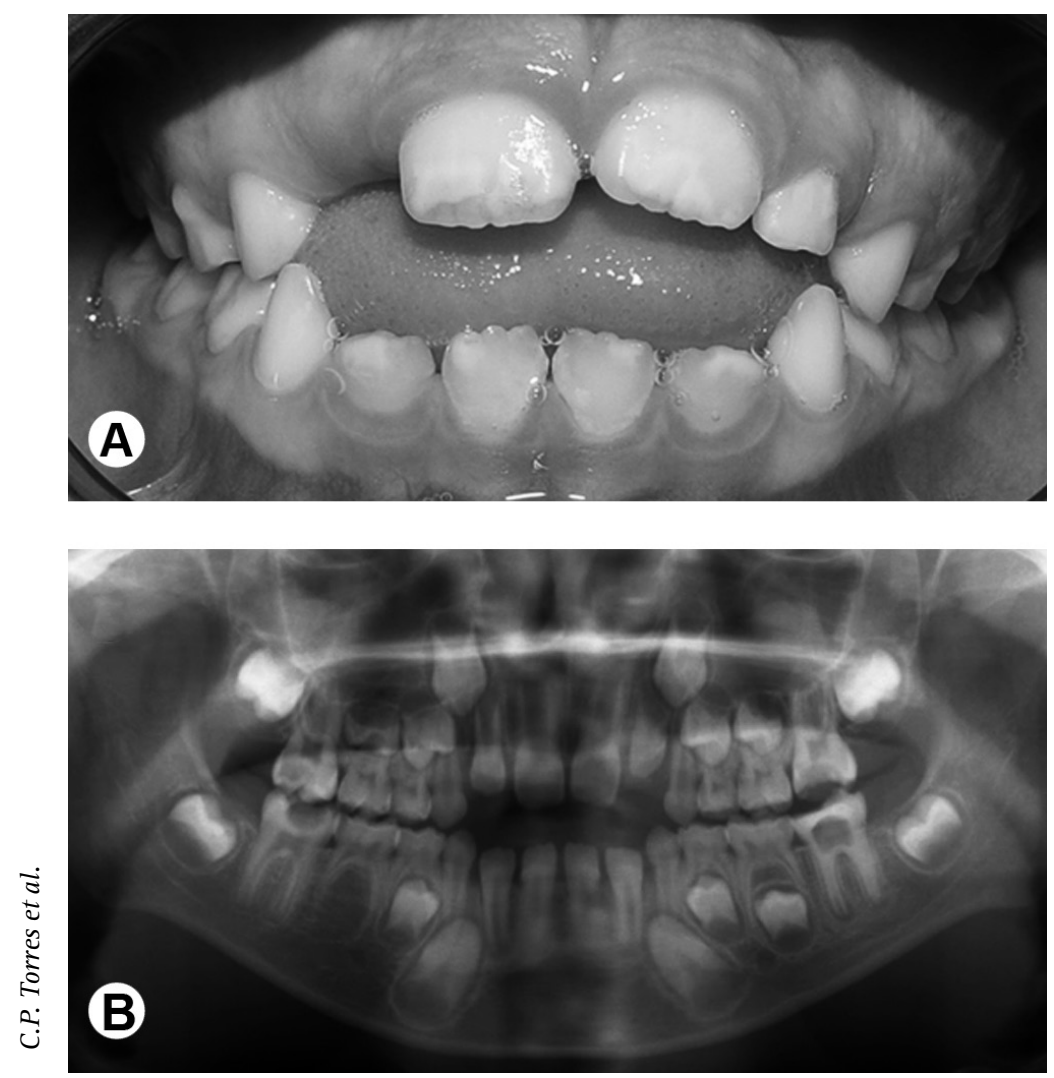

Figure 3. Intraoral clinical view: A: anterior open bite, tongue thrusting, excessive interdental spacing and enamel hypomineralization of the incisors; B: panoramic radiograph showing agenesis of the mandibular right premolar and hypoplasia and caries lesions in the maxillary and mandibular first molars.
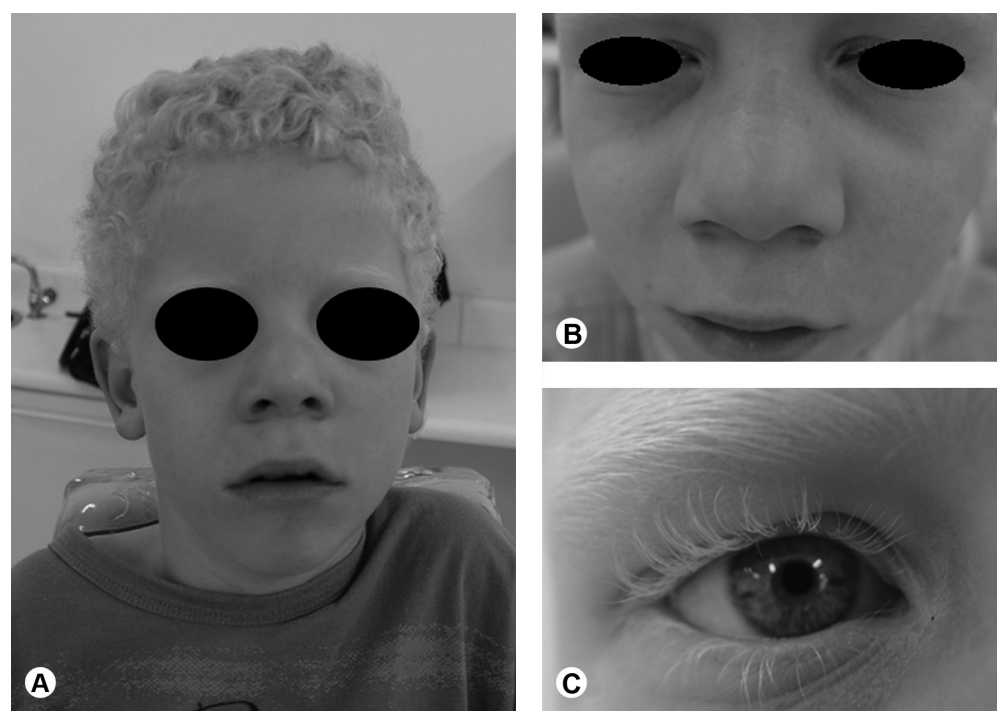

Figure 2. Craniofacial findings: A: facial aspect; B: depressed nasal bridge with broad nasal tip, anteverted nostrils and long philtrum; C: stellate pattern of iris. offered during the treatment sessions. The use of music and sunglasses made the treatment sessions more pleasant to the child and produced a significant improvement of his behavior, with a decisive role in the achieved success.

A two-phase treatment was planned for this case. In the first phase, therapy/noninvasive treatment were applied, including oral hygiene instructions, dietary counseling in the form of a 5-day dairy diet to reduce the child's intake of sucrose, and daily use of a $0.05 \%$ sodium fluoride mouthwash. Because of the patient's high caries risk, in-office dental care included rubber cup/ pumice prophylaxis, $0.12 \%$ chlorhexidine gluconate mouthrinse (Periogard ${ }^{\oplus}$; ColgatePalmolive, New York, NY, USA) and topical applications of $1.23 \%$ acidulated phosphatefluoride gel (Sultan Topex ${ }^{\circledR}$; DFL Ind. e Com. Ltda., Petrópolis, RJ, Brazil). The second phase was restorative. The mandibular left first molar was treated endodontically. Maxillary and mandibular first molars were restored with amalgam. Due to the patient's heart defect, a prophylactic antibiotic regimen was prescribed prior to the dental procedures, following the guidelines of the American Heart Association (10), which recommends $2 \mathrm{~g}$ amoxicillin $1 \mathrm{~h}$ before the procedure for patients above $40 \mathrm{~kg}$ body weight.

As the child was considered a highcaries-risk patient, the AAPD Policy on use of a caries-risk assessment tool (CAT) for infants, children, and adolescents (20112012) (11) was followed after completion of the restorative phase, including followup visits every 3 months for professional prophylaxis sessions and topical fluoride applications, radiographs every 6 months, sealant placement for teeth with deep fissure anatomy or developmental defects, and constant reinforcement of diet counseling.

Case progression is under continuing evaluation and satisfactory outcomes have been maintained since the end of the restorative phase. This patient has been followed for 4 years.

\section{Discussion}

WBS is a rare genetic condition of sporadic occurrence in most cases. The patient of this case was born to healthy 
parents and had no family history of the syndrome.

Although this patient is a very communicative child and attends normal school, he has motor and intellectual deficit, presenting difficulties for developing school activities, as described for other patients with WBS (2). He has some of the typical features of WBS namely, medial eyebrow flare, flat midface, periorbital fullness (puffy eyes), epicanthal folds, long philtrum, depressed nasal bridge with broad nasal tip, anteverted nostrils, curly blond hair, stellate pattern of iris, green eyes, strabismus, visual impairment, sensorineural hearing loss, hyperacusis, photophobia and hoarse voice $(4,8,12-14)$. He also has a congenital heart defect, which is a common finding in these patients (15). The fact that the patient is albino is probably not related with the syndrome and is more likely simple coincidence.

Regarding the oral findings, some authors (4) evaluated 45 patients with WBS and observed hypodontia in 11.1\% of the sample, abnormal tooth morphology was noted in $12.5 \%$ of the primary teeth, and $40.7 \%$ of the permanent teeth. Except for the primary mandibular central incisors of males, all mesiodistal incisor crown dimensions were significantly smaller when compared to patients without the syndrome. At least one hypoplastic enamel defect was present in $9.4 \%$ of patients with primary teeth and in $18.5 \%$ with permanent teeth. No patient exhibited generalized enamel hypoplasia. More than half of the patients (59.1\%) were both caries- and restoration-free, while only $13.6 \%$ presented clinically active caries. Tongue thrusting was present in $67.7 \%$ of the sample, while more than $50 \%$ of the patients presented excessive interdental spacing. Patients exhibited a higher prevalence of Class II and III occlusions, open and deep bites and anterior crossbites. Axelsson et al. (2003) (16) described dental characteristics in a group of 41 individuals more than 10 years old with Williams syndrome. The authors observed that $40.5 \%$ of the patients had agenesis of one or more permanent teeth and 11.9\% had agenesis of 6 permanent teeth or more. Furthemore, the evaluation showed that a high proportion of maxillary and mandibular incisors were tapered or screwdriver shaped.

A recent study (6) examined four patients with WBS. In all of them the agenesis of two or more teeth were observed and considerable malocclusions (open bite, cross bite and deep bite malocclusion) were present too. In this patient, some of these features were present, such as anterior open bite, tongue thrusting, excessive interdental spacing and hypoplasia. Additional findings were observed in this child, such as caries lesions in the maxillary and mandibular first molars, enamel hypomineralization of the incisors and agenesis of the mandibular right premolar.

Cingano et al. (6) observed a higher incidence of gingival and periodontal diseases in the WBS patients. The authors explain this fact by the poor oral hygiene practices, due the lack cooperation of the young patients, and also association with the malocclusion and agenesis that limited the self-cleansing. Furthermore, an important point revealed by these authors concerns the gene responsible for the formation of elastin, which is missing in the WBS patients. This gene is located in chromosome 7, which was missing in this syndrome. The elastin is an essential component of connective tissue. So, the authors concluded that the high incidence of gingivitis and periodontitis observed in the patients they examined could be also explained by the severe alteration of elastin components of gingival connective fibers, increasing the susceptibility of periodontal tissue to be attacked by plaque bacteria.

According to Ji et al. (17) children with WBS have been found to have poor daily living and motor skills. In a study with 26 children with WBS, the authors explore the adaptive behavior of these patients and they observed that independence training and education regarding effective interventions might reduce dependency in adulthood and promote heightened skills and abilities. The limited motor skills shown in patients with WBS contributed to a poor oral hygiene, requiring a comprehensive preventive approach to reduce the caries risk and activity. The patient was treated in the outpatient pediatric dentistry clinic under local anesthesia, after use of the AAPD basic behavior guidance (9) associated with stimulation of tactile sensation of the instruments to be used, because of his significant visual impairment. The use of music and sunglasses were artifices that brought great contribution to the success of the treatment sessions as the patient had strong attraction to music and hypersensitivity to light. In addition, the use of headphones minimized the sounds and noises of the dental office, which caused great discomfort to the child due to his hypersensitivity to loud sounds. After only a few modulating sessions, the patient's uncooperative and hyperactive behavior improved considerably, and he became very cooperative and friendly with the dental staff, allowing treatment without need of sedation. The benefits of the ambulatory treatment include the possibility of undertaking less invasive dental procedures, lower cost and absence of hospitalization, thus eliminating the risks inherent to general anesthesia procedures and hospital infection.

Early dental evaluation and parental counseling are important in patients with WBS because the development of caries lesions and endodontic infections may have more serious complications in these individuals, as the high incidence of congenital heart defects increases the risk of subacute bacterial endocarditis. Enamel structural defects are common in these patients, causing great coronal destruction and even tooth loss if early intervention is not done. Preventive dental protocols and dietary counseling must be individually designed and implemented. When 
dental procedures are needed, the administration of antibiotics prior to the treatment is indicated advised as prophylaxis for bacterial endocarditis. A comprehensive radiographic examination will reveal the presence of dental anomalies, which are typical findings of WBS, and help planning the restorative and orthodontic rehabilitation. Whenever possible, the control of hyperactive and uncooperative behavior should be attempted using behavioral management techniques to allow for dental treatment under local anesthesia in the dental office.

\section{Resumo}

A Sindrome de Williams-Beuren (SWB), também conhecida como síndrome de Williams, consiste em uma desordem congêntica rara a qual apresenta problemas cardiovasculares, retardo mental, alterações faciais e anomalias dentárias. É causada pela microdeleção de 1,5 a 1,8 Mb no cromossomo 7q11.23. Este trabalho relata o tratamento odontológico de uma criança de 7 anos com a sindrome. Durante a anamnese constatou-se deficiência visual, perda auditiva neurossensorial, hiperacusia, fotofobia e voz rouca. 0 exame clínico intra-oral revelou mordida aberta anterior, deglutição atípica, espaçamento interdental excessivo, hipomineralização dos incisivos, hipoplasia e lesões de cárie. 0 tratamento dentário incluiu:sessões de condicionamento comportamental afim de controlar a aversão a ruídos, a fotofobia e o medo e a ansiedade frente ao tratamento odontológico, provocadas principalmente por sua reduzida acuidade visual; instruções de higiene oral, dieta e uso diário de bochechos de fluoreto de sódio a 0,05\%; endodontia do primeiro molar permanente inferior esquerdo e restaurações de amálgama nos primeiros molares superiores e inferiores. Devido ao defeito cardíaco do paciente, antibioticoterapia profilática foi realizada antes dos atendimentos odontológicos. Este paciente está . em acompanhamento há 4 anos e este relato ressalta a importância

¿̇ da avaliação odontológica precoce e do aconselhamento aos pais dos pacientes com SWB.

\section{References}

1. Nikitina EA, Medvedeva AV, Zakharov GA, Savvateeva-Popova EV. Williams syndrome as a model for elucidation of the pathway genes the brain - cognitive functions: genetics and epigenetics. Acta Naturae 2014;6(1):9-22.5.

2. Kaplan P, Wang PP, Francke U. Williams (Williams Beuren) syndrome: a distinct neurobehavioral disorder. J Child Neurol 2001;16:177-190.

3. Strømme P, Bjørnstad PG, Ramstad K. Prevalence estimation of Williams syndrome. J Child Neurol 2002;17:269-271.

4. Herzberg J, Nakisbendi LA, Needleman HL, Pober B. Williams syndrome: oral presentation of 45 cases. Pediatr Dent 1994;16:262-267.

5. American Academy of Pediatrics. Health care supervision for children with Williams syndrome. Pediatrics 2001;107:1192-1204.

6. Cingano $L$, Servetto $R$, Loria $P$, Calcagno E. Odontostomatological aspects in patients with Williams syndrome: a series of 4 cases. Minerva Stomatol 2013;62:447-454.

7. Moskovitz M, Brener D, Faibis F, Peretz B. Medical considerations in dental treatment of children with Williams syndrome. Oral Surg Oral Med Oral Pathol Oral Radiol Endod 2005;99:573-580.

8. Campos-Lara P, Santos-Diaz MA, Ruiz-Rodriguez MS, Garrocho-Rangel JA, Pozos-Guillén AJ. Orofacial findings and dental management of Williams-Beuren syndrome. J Clin Pediatr Dent 2012;36:401-404.

9. American Academy on Pediatric Dentistry Clinical Affairs CommitteeBehavior Management Subcommittee; American Academy on Pediatric Dentistry Council on Clinical Affairs. Guideline on behavior guidance for the pediatric dental patient. Pediatr Dent 2011-2012;33(6 Suppl):161-173.

10. Wilson $\mathrm{W}$ et al.. Prevention of infective endocarditis - Guidelines from American Heart Association. Circulation 2007;116:1736-1754.

11. American Academy on Pediatric Dentistry Council on Clinical Affairs:
Policy on use of a caries-risk assessment tool (CAT) for infants, children, and adolescents. Pediatr Dent 2011-2012;33:110-117.

12. Ohazama A, Sharpe PT. TFII-I Gene family during tooth development: candidate genes for tooth anomalies in Williams Syndrome. Dev Dyn 2007;236:2884-2888.

13. Mass $E$, Oelgiesser $D$, Tal $H$. Transitional implants in a patient with Williams-Beuren syndrome: a four-year follow-up. Spec Care Dent 2007;27:112-116.

14. Weber SL, Souza RB, Ribeiro LG, Tavares MF, Goldchmit M. Williams Syndrome: Ophthalmological examination and review of systemic manifestations. J Pediatr Ophthalmol Strabismus 2014;30:1-5.

15. Sugayama SMM, Leone C, Chauffaille M de LLF, Okay TS, Kim CA. Williams syndrome. Development of a new scoring system for clinical diagnosis. Clinics 2007;62:159-166.

16. Axelsson S, Bjørnland T, Kjaer I, Heiberg A, Storhaug K. Dental characteristics in Williams syndrome: a clinical and radiographic evaluation. Acta Odontol Scand 2003;61:129-136.

17. Ji C, Yao D, Chen W, Li M, Zhao Z. Adaptive behavior in Chinese children with Williams syndrome. BMC Pediatr 2014;14:2-6.
Received March 19, 2014 Accepted March 25, 2015 